\title{
Human Resource Management Practices in Nigeria
}

\author{
Sola Fajana \\ Department of Industrial Relations and Personnel Management \\ Faculty of Business Administration, University of Lagos \\ Oluwakemi Owoyemi (Corresponding author) \\ Department of Industrial Relations and Personnel Management \\ Faculty of Business Administration, University of Lagos \\ E-mail: oowoyemi@unilag.edu.ng \\ Tunde Elegbede \\ Department of Industrial Relations and Personnel Management \\ Faculty of Business Administration, University of Lagos \\ E-mail: telegbede@unilag.edu.ng \\ Mariam Gbajumo-Sheriff \\ Department of Industrial Relations and Personnel Management \\ Faculty of Business Administration, University of Lagos \\ Email: mgbajumo@unilag.edu.ng
}

Received: February 24, $2011 \quad$ Accepted: April 18, $2011 \quad$ doi:10.5430/jms.v2n2p57

\begin{abstract}
The globalization of business is having a significant impact on human resource management practices; and it is has now become more imperative than ever for business organizations to engage in human resource management practices on an international standard. While the management of people is mostly associated with HRM, the definition, parameter and context are contested by different writers. Some authors such as Kane (1996) argued that HRM is in its infancy, while other authors such as Welbourne and Andrews (1996) dispute it. However, other writers have attempted to differentiate between personnel management and HRM (Sisson, 1990), by emphasizing on the strategic approach to managing people. Other writers such as Legge (1995) have focused on the soft and hard approach to managing human resources. All these distinctions have contributed to the fundamental differences in understanding and defining human resource management practices, and therefore, HRM should not be incorporated within a single model, but rather adequate emphasis should be on understanding human resource management issues, which will assists practitioners, authors, mangers and organizations in developing and implementing HRM policies and practices that will be productive and that can make businesses to gain and sustain a competitive advantage. This is paper is aimed at exploring HRM practices in Nigeria.
\end{abstract}

Keywords: Human resource management, Strategic HRM, Management, Culture, Organisation

\section{Introduction}

HRM is a distinctive approach to employment management which seeks to achieve competitive advantage through the strategic development of a highly committed and capable workforce using an integrated array of cultural, structural and personnel techniques (Storey, 2001). Beer et al, (1984) defined HRM as a strategic approach to the management of human resources that involves all management decisions and actions that affect the relationship between the organisation and employees. While Armstrong (2006) defines HRM as a strategic, coherent and comprehensive approach to the management and development of the organisation's human resources in which every aspect of that process is wholly integrated within the overall management of the organisation. Schuler and Jackson (1987) develop the strategic model of HRM by linking HR practices to competitive strategies framework that an organisation can use to gain competitive 
advantage. They argue that the strategy that management of an organisation employs can affect the kind of employees' behaviour. However, this strategic model of HRM is not left with some flaws such as ignoring the employees' interest, not recognising the legal requirement, social norms and values of the environment in which they operate (Legge, 1995:115; Budhwar and Debrah, 2001: 500). The strategic model according to Legge labels this model as the hard HRM model, which contrast totally from the 'soft model' of HRM that emphasises commitment HR strategy. This commitment strategy model was as a result of the interest in the cultural factors that has promoted the Japanese economic performance making the country to have a competitive advantage over countries in the late 1970 to 1980 . Looking at these three definitions of what HRM is, there is a major area of convergence, which is the 'Strategic' nature of the management approach. These definitions have encompassed the linking of various HRM practices such as recruiting, selection, rewarding, training, appraising and planning with organisational goals. Hence, strategic HRM is a more integrative HRM practice that links the organisational goals with the strategic management process (Sparrow, Brewster $\&$ Harris, 2004)).

All these definition indicates that HRM is an elusive concept with various meanings; deciding on an accepted definition will lead to confusion. That is why Storey (2001) argues that HRM is elastic and it covers a range of applications that varies from books, society and organisations. Moreover, in defining, HRM, these three components should guide how the concept can be operationalised.

\section{H: Human (something to do with people)}

\section{M: Management places domain of Business and Organisation}

\section{$R$ : Ambiguous concept that people find it difficult to relate to.}

According to Price (2000), much academic literature have forgotten the human element in HRM, rather people have been tagged as a 'resource' along with other resources such as tables and desk. Price (2000) believed that people cannot be discussed and treated in exactly the same manner as equipments. The 'human' aspect of HRM is concerned with the relationship between employer and employee and it associated with the human relations movement and the concept of high commitment work practices developed by (Walton, 1985). This model defines HRM as the softer issues of strategic management (Beer et al, 1995). That is why HRM should therefore be part of management strategies concerned with the decisions, strategies, factors, principles, operations, practices, functions and methods related to the management of people as employees in any type of organisation (Steering Committee for HRM Standards \& Qualification in South African, 1999).

In order for HRM to function very well, Price (2000) argued it has to be pragmatic (aims to achieve practical solutions to real work problems) and eclectic (the solutions can be drawn from a variety of theoretical \& managerial traditions. Given all these arguments, HRM is a philosophy of people management based on the belief that human resources are uniquely important to sustain business success; and an organisation gains competitive advantage by using its people effectively, drawing on the expertise to meet clearly defined objectives (American Management Association, 2000). As the management of an organisation is accountable for obtaining and maintaining qualified employees, in today's complex environment, fulfilling that mission is a major contribution to an organisation's success (American Management Association, 2000).

There are three levels at which HRM can be operationalised following Budhwar and Sparrow (2004:7) which are national level (this involves the external labour market, national culture, social-cultural environment, legislations); contingent variables (such as the type and the nature of business, ownership, age etc); organisational strategies (this relates to the HR functions and the internal labour market). This framework will be the basis on which HRM practices in Nigeria will be based on. However, this model should be treated with some caution because Budhwar and Sparrow (2004) developed this framework to analyse issues of HRM in different countries.

\section{HRM in Nigeria}

HRM policies and practices are carried out within an economic, social, political and legal environment. Thus, there is a need for considerable historical and cultural insight into local conditions to understand the processes, philosophies and problems of national models of HRM (Hofstede, 1993). Nigeria is the most populous country in Africa with an estimated population of 180 million people. The Nigeria's population and human resource base make it one of the most attractive countries for foreign investment in Africa. As foreign and local firms increase their involvement in Nigeria, they will need to build capabilities and utilise local competencies. The knowledge of human resource management (HRM) and more importantly perhaps, knowledge of the factors that impact on HRM in Nigeria will become increasingly critical to the way we do businesses in Nigeria and ultimately their success. Hence, the way to get things done cannot be divorced from local values, customs, and the overall external cultural environment. 
HRM as a concept got introduced into the Nigeria literature in 1940 during the colonial era; with industrialisation and commercializstion, which later became wage employment. Ever since then, there has been a tremendous growth of HR in Nigeria, which in recent years has been characterised by lack of professionalism and specialisation. Different reasons have been accounted for as the challenges facing HRM practices in Nigeria. Some of which are discussed in this paper. The socio-cultural diversity of Nigeria has influenced the HRM practices in Nigeria. Nigeria is characterised by over reliance on culture, language, religion, gender and educational qualifications as a basis for determining who get employed. What this means is that, the opportunity for an average Nigeria to get employed is a factor of the aforementioned variables.

Nigeria according to Fajana (2009) is one of the African countries troubled by abundant labour and scare talent. Attracting, developing, deploying and retaining best talents had become a challenge. That is why Fajana and Ige (2007) argued that the desire for top performance has driven the need for effective management. HRM in Nigeria can be said to be 'still in Infancy' and lot of academic research is still required in this area. Lack of indigenous and comprehensive HRM models is one of the challenges facing HRM practices in Nigeria, which is why the majority of principles and practices evidence in workplaces in Nigeria are all adopted from other countries. HRM practices in Nigerian are a convergence with western-inspired approaches, with the evidence of cultural and institutional influences on it. That is, there is a blend of transplanted and indigenous HRM practices. The sensitivity to individuals' socialization as well as economic, historical, political, and social contexts according to Azolukwam and Perkins (2009) may enable organisations to capitalise on the potential to transplant forms of HRM from parent country cultures to developing countries such as Nigeria.

Nevertheless, most organizations are characterized by lack of funding for human resource management research and development. Nigeria's democracy has enhanced the practice of HRM, determining the quota of expatriates it permits. Nigeria's economy allows the importation of new technologies to enhance HRM, but training is still a bit slow, thus employment of expatriates to handle such is still encouraged. In Nigeria, there is application of new management techniques and skills used in the running of organizations, all aimed at running a cost- effective system. HRM practices in Nigeria cannot be totally diffused from what is evidence in other countries. However, due the peculiarity of the social-cultural characteristic of Nigeria, HRM in Nigeria is an area open for further research. Good employer-employee relations are therefore critical to the stable and sustainable development of the Nigerian economy, as well as the world economy as a whole. Several other factors have affected HRM practices in Nigeria namely; first, lack the internal manpower to complete all necessary tasks. Second, the complexity of today's business climate as a result of deregulation, globalization, and technology advancements has outpaced many companies' level for companies to get special projects done without adding employees to the payroll (Olofin \& Folawewo, 2006).

Most organizations in Nigeria now offer a continued education and training to help its people cultivate the right skills and expand their career within a truly global/collaborative workplace. However, in recent time, Nigerian workplaces are introducing different HR ideologies adopted from foreign organizations. For instance, there has been a tremendous increase in level of contract or temporary employment and most of these activities are contracted out to consultants, via outsourcing thereby reducing the number of personnel in its payroll. The implication of this is that organizations are paying lesser for more work, and at the same are losing the psychological attachment, commitment, loyalty of their employees.

In Nigeria, organizational control is firmly in the hands of management and the management's role is to effectively manage the number of employees and match them closely with desired goals and objectives. Both the management and the Nigerian government strive to make coherent HR policies that fit closely with overall business strategy. For example, in the oil industry (which is the most organized and highly paid employment sector) the government of Nigeria has made concerted efforts over the last 50 years to promote the participation of indigenous workers in the oil industry. Regulation 26 of the 1969 Petroleum and Drilling Act represents one of government's early efforts to increase Nigerian national oil workers' participation in the industry. Recruitment is selectively done in Nigeria, and employees are trained to perform required skills. However, due to the complexities involved in the activities of the oil industries, a lot of skilled expatriate services are required leading to a high level of expatriate employment till date. This is also because most of the oil companies are multinationals, with parent companies in well-developed and advanced countries.

For most organizations in Nigeria, performance appraisal is a dialogue process and serves as a mentor to generally mould the individual to perform at an optimal level. The employees are allowed to carry out a self-evaluation based on engagements and projects they were involved in during the assessment period. It is expected that performance appraisal system should be a fair process involving assessments on skills, technical knowledge and how well the employee can offer quality service delivery. However, the lack of skill and know-how of the appraiser have made some of the tools and 
parameters for appraising employees' performance to be faulty. Such appraisal system and process might not capture what it is expected to. The concern to develop the right performance appraiser system have pushed indigenous companies in Nigeria to employ expatriate services, as trainers, in positions requiring special skills and expertise, with which Nigerian workers cannot compete. These supervisors assess the performance and recommend for promotions as the case may be.

Wages and other fringe benefits in organizations in Nigeria are by collective bargaining between unions and employers or employees' association. In some private organizations, the basic wages are generally higher than the public sector organization. What is evidence in Nigeria is that wage scales are based on job analysis and evaluation to ensure equity and increases are based on merit or performance. The higher the risk, time allocation, skills requirement, experience required, the higher the wage. That is why jobs that are high in occupational hazards are the highest paid job in Nigeria. In the case of public sector organizations owned by Government, salary adjustments may result from annual merit reviews, promotions, individual special adjustment or general adjustments. General adjustments are made when the Government decrees a general wage increase in both the public and private sectors.

In recent years, most organizations in Nigeria are now re-emphasizing the need to train their employees. Training is expected to generate enthusiasm for creating new ideas, and is mutually beneficial to employers and employees. Managers, supervisors and HR departments are responsible for ensuring that workers are effectively trained. Some organizations in Nigeria now provide workers with education and subsidies for job-related training; while some other organizations have changed their wage structures to include education and training subsidy allowance in workers' wages. The challenge here is that such training is expected to be job-related and proven to be of mutual benefit to both employers and employees. This can limit the employees from acquiring others skills that are not related to the job description. Nevertheless, most organisations in Nigeria are constantly aware of the need and relevance of training and they equally design the right training to meet identified needs. This will ensure that they have the right crop of qualified, competent and valuable professionals to make the right input and be knowledgeable in diverse fields.

Another area of HRM practices that need further development and enhancement is the occupational health and safety. There has not been reliable official statistics on the number of fatalities and non-fatalities in organizations in Nigeria. This is because most organizations are not willing to share their experiences with other because of the fear or being accused of not handling health safety issues properly and compensating the victims adequately. There is also the challenge of employees in Nigeria not knowing there right to work in a safe environment free of occupational hazards and appropriate compensation in the case of accidents or hazards that can affect them both psychologically and physically.

Most organizations in Nigeria are highly unionized, especially the public sector organizations. Employees unite to protect and promote their interest, so also do the employers. Until March 2005, the Government of Nigeria promoted compulsory union membership at the workplace, which has resulted in almost 60 per cent unionization rate. For instance, oil the workers are unionized by occupational category: white-collar workers belong to the Petroleum and Natural Gas Senior Staff Association (PENGASSAN) and production workers to the National Union of Petroleum and Natural Gas Workers (NUPENG). Some of industry-wide trade unions affiliate with different national unions, such as the Trade Union Congress of Nigeria (TUC) and the Nigeria Labour Congress (NLC), respectively. It is only the private organizations that there has not been a high participation in union. Rather what we have in some of these private organizations is employers and employees forming and meeting at common forums to discuss issues, identified problems and map out strategies for a better working relationship.

\section{Lessons from the experience of other countries}

Human resource managers and practitioners in Nigeria can learn and adopt the following best practices from other developed countries:

$\checkmark$ Openness and objectivity of the recruitment and selection process

$\checkmark \quad$ Strategic development of staff for optimal utilization

$\checkmark \quad$ Flexibility in pay system

$\checkmark$ Balance of power in the application of equal employment opportunity

$\checkmark \quad$ The efficiency of affirmative action in ensuring employment opportunity

$\checkmark$ Group harmony which can enhance cooperation and decision-making 


\section{Conclusion}

The socio-cultural diversity of Nigeria has influenced the HRM practices in Nigeria. Both the management and the Nigerian government should strive to make coherent HR policies that fit closely with overall business strategy. Employment discrimination has not been adequately addressed because of the 'quota system' that is still present is most of the public service organisations. Lastly, most organizations in Nigeria are highly unionized, especially the public sector organizations and employees unite to protect and promote their interest, so also do the employers. While in the private organizations, that there has not been a high employees' involvement in union activities. It is obvious that HRM practices in Nigeria has not been fully developed and there is the urgent need to employ the services of HR professionals, consultants and researchers to help shape and develop new directional focus that will ensure an efficient and effective human resource practice in Nigeria.

\section{References}

American Management Association (2000) Auditing your Human Resources Department AMACOM.

Azolukwam, V. and Perkins, S. (2009) Managerial perspectives on HRM in Nigeria: evolving hybridization?', Cross Cultural Management: An International Journal, vol 16, 1, pp5-27. doi:10.1108/13527600910930040, http://dx.doi.org/10.1108/13527600910930040

Beer, M., Spector, B., Lawrence, P. ., Mills, D. and Walton, R. (1984)A Conceptual View of HRM in Managing Human Assets. Free Press, New York.

Budhwar, P. and Debrah, Y. (2004) Introduction: HRM in Developing Countries. In P. Budhwar and Y. Debrah (Eds.) HRM in Developing Countries. London: Routledge.

Budhwar, P. and Sparrow, P (2002), An integrative framework for understanding cross-national HRM practices, Human Resource Management Review, Vol. 12 No.3, pp.377-403. doi:10.1016/S1053-4822(02)00066-9, http://dx.doi.org/10.1016/S1053-4822(02)00066-9

Fajana, S. (2002) Human Resource Management: An Introduction, Lagos

Fajana, S. (2009) HR Management in Africa: The Social and Economic Framework, Personalfuhrung ,7, pp. 8086

Fajana, S. and Ige, A. Y. (2009) Globalisation and International Labour Mobility: An in-depth study of the Nigerian Health Sector, Conference of Marco Biangi Foundation. Modena / Italy.

Hofstede, G. (1980) Culture's consequences: international differences in work - related values, London, Sage.

Hofstede, G. (1991) Culture and Organisations: software of the mind, London, Harper Collins Business.

Kane, B. (1996) HRM: changing concepts in a changing environment", International Journal of Employment Studies, Vol. 4 Issue 2, pp.115-177. doi:10.1177/103841110003800103, http://dx.doi.org/10.1177/103841110003800103

Legge, K. (1995) Human resource management: Rhetorics and Realities, London, Macmillan.

Olofin, S. O. and Folawewo. A. O. (2006) Skill Requirements, Earnings and Labour Demand in Nigeria's Urban Informal Sector. In B. Guha-Khasnobis and R. Kanbur, eds., Informal Labour Markets and Development. Palgrave Macmillan: 180-195,Paper prepared for the joint WTO-ILO Workshopon Global Trade and Employment, 31 August - 1 September, 2009, Geneva, Switzerland

Price, A. (2000) Principles of Human Resource Management: An Action-Learning Approach, Blackwell, Oxford

Rowley, C., Benson. J and Warner, M. (2004) Towards an Asian model of human resource management? A comparative analysis of China, Japan and South Korea, International Journal of human resource management 15:4 June/15:5 August P.917-933. doi:10.1080/0958519042000192013, http://dx.doi.org/10.1080/0958519042000192013

Schuler, R. and Jackson, S. (1987) Linking competitive strategy with human resource management practices, Academy of Management Executive, Vol 3, pp 207-219. doi:10.5465/AME.1987.4275740, http://dx.doi.org/10.5465/AME.1987.4275740

Sisson, K. (1990) Introduction: Human Resource Management Journal, Vol. 1, No. 1, pp. 1-2 Steering Committee for HRM Standards and Qualification in South African (1999) Assessed 22 $2^{\text {nd }}$ September 2010, http://www.scribd.com/doc/3266422/scope-of-hrm

Sparrow, P., Brewster,C. and Harris, H. (2004) Globalizing human resource management, London, Routledge. 
Storey, J. (2001) Introduction: From Personnel Management to Human Resource Management, A critical Text, Thomson Learning. London.

Walton, R. (1985). Toward a strategy of eliciting employee commitment based on policies of mutuality. In R. E. Walton \& P. R. Lawrence (Eds.), Human resource management: Trends and challenges. Boston: Harvard Business School Press.

Welbourne, T. and Andrews, A (1996) 'Predicting the performance of initial public offerings: Should human resource management be in the equation? 